\title{
Л. Б. СЛЕПЯН
}

11 октября 1959 г. после непродолжительной болезни скончался старейший ученый в области радиотехники, заведуюший кафедрой радиотехники Северо-Западного заочного политехнического института профессор Леопольд Борисович Слепян. Не так давно, в феврале 1959 г. научно-техническая общественность отмечала 70-летне со дня рождения н 45-летие научно-технической деятельности этого выдающегося ученого, желая ему долгих лет жизни и дальнейших творческих успехов в его плодотворной научной и педагогической деятельности. Тем острее чувствуется сейчас горечь утраты этого замечательного человека и видного ученого.

Коллектив профессоров, преподавателей и студентов Северо-Западного заочного политехнического института, института связи, научноисследовательского института радиоприема и акустики им. А. С. Попова, Института авиащионного приборостроения, виднейшие ученые и радиоспециалисты Ленинграда, студенты и сотрудники покойного выразили глубокую скорбь по поводу зтой тяжелой утраты.

Леопольд Борисович окончил в 1913 г. электромеханическое отделение Петербургского политехнического института и был оставлен аспирантом на кафедре профессора, впоследствии академика $В$. Ф. Миткевича, чьнм учеником проф. Слепян себя считал всю свою жизнь. Начиная с 1916 г.,
Л. Б. Слепян начал работать по сcновным вопросам новой для того времени области науки - радиотехники. В том же году Леопольд Борисович поступил в лабораторию старейшего радиотехнического завода им. Қозицкого, где он работал в качестве ассистента академика Л. И. Мандельштамма. Позднее, с организацией в Ленинграде цент- ральной радиолаборатории, Леопольд Борисович возглавил отдел радиоприемныХ устройств.

Не порывая тесной связи с промышленностью, Леопольд Борисович большую часть своей жизни отдал работе в высших учебных заведениях г. Ленинграда. С 1933 г. он являлея руководителем кафедры радиоприемных устройств Института инженеров связи им. М. А. Бонч-Бруевича, с 1947 г. заведовал кафедрой теоретинеской электротехники в институте точной механики и оптики, а в последние годы руководил кафедрой радиотехники в СевероЗападном заочном политехническом институте. Наряду с педагогической слитле дельностью Леопольд Борисович непрерывно прннимал участие в научно - исследовательской работе ряда научно-исследовательских институтов и заводских лабораторий.

Перу Л. Б. Степяна принадлежит ср!шше 60 опубликованних научных работ. Большинство его теоेретических исследований воюло в учеб. ники по технике радиоприема. Его учебник по радиоприемным устройствам, изданный в $30-x$ годах, до сих пор не потерял своей ценности.

Еше на заре своей юності, Леолольд Борисович был принят в члены Русского Физико-химического общества, а с момента организации. Общества им. А. С. Попова он стал его активным членом.

Партия и Правительство высоко оценили научную и педагогическую деятельность проф. Слепяна, наградив его огденом и медалями.

Память о Леопольде Борисовиче Слепяне, видном угеном и замечательном человеке надолго сохранится в сердцах тех, кто знал его, учился у него и fаботал вместе с ним.

Доц. к. т. н. Ю. В. Рогинский 